\begin{tabular}{lll} 
KULTURA & $\begin{array}{l}\text { POLSKA A KADEMIA NAUK } \\
\text { KOMITET SOCJOLOGII }\end{array}$ & ISSN 0023-5172 \\
i & $\begin{array}{l}\text { INSTYTUT STUDIÓW POLITYCZNYCH } \\
\text { SPOLECLENSTWO nr } 3 \quad \text { AUTOETNOGRAFIA }\end{array}$ & \\
\hline
\end{tabular}

KRYSTIAN DARMACH

Uniwersytet Łódzki

Katedra Studiów Latynoamerykańskich i Porównawczych

\title{
AUTOETNOGRAFIA 2.0
}

Metodologiczny dziennik pisania tekstu o autoetnografii. Autoetnograficzny dziennik pisania metodologicznego tekstu o autoetnografii. Metaautoetnografia. Autotranscendencja. Rekurencja. Brzmi jak tautologia, lecz zestawienia powyższych pojęć i znaczeniowe napięcia między nimi zachodzące nie są bezpodstawne. Wynikają z pytania o to, jakim językiem pisać i jaką formułę tekstu przyjąć, by treść swej refleksji dotyczącej przedmiotu (i podmiotu) zainteresowania możliwie najpełniej wyrazić. Szczerze, rzetelnie i „po swojemu”.

Jestem konstelacją. Punktem przecięcia, pryzmatem uwarunkowanym przez szereg (także tych nieuświadomionych) kulturowych konstytucji. W trakcie pisania, a wcześniej w trakcie badawczego przedsięwzięcia, dają one znać o sobie w rozmaitych konfiguracjach i kontekstach. Zaskakują i inspirują, wprawiając w ruch refleksję, odsłaniając zarówno te jasne, jak i ciemniejsze strony własnego procesu rozumienia i wyjaśniania - ukazując ich nieoczywiste, a komplementarne warstwy. W odniesieniu do siebie, do języka i wypracowanej w ramach naukowej wspólnoty terminologii danej dziedziny wiedzy, warunków prawomocnego myślenia, metodologii i przede wszystkim szeroko rozumianego doświadczenia.

Od doświadczenia do metaautoetnografii prowadzi długa droga. Kręta i wyboista. Pełna nakazów, zakazów, zmiennych prędkości i nieoczekiwanych zwrotów. Teoria i metoda jest mapą i ekwipunkiem pozwalającym rozpoznawać teren. Dopiero doświadczenie ukazuje naszą zręczność w posługiwaniu się nimi, ich przydatność i możliwości. Bycie w drodze jest pełne niespodzianek, zawra- 
cania, porzucania idei i koncepcji, rezygnacji i zatrzymań... narracja się rwie, gubi, myśli błądzą, nasze oczekiwania, hipotezy i założenia zawodzą. O tym, jak ważne dla wyników, efektów czy jakości zebranego materiału są rzeczy zupełnie prozaiczne, subiektywne i zwykle „zamiatane pod dywan”, przekonałem się podczas wielu prób badawczego, antropologicznego oglądu kulturowej rzeczywistości mającego zakończyć się pisemną praca, dysertacją, sprawozdaniem, esejem lub innego rodzaju sformalizowanym tekstem. Doświadczałem metodologicznego rozbicia, poczucia niewspółmierności metodycznych wymagań i biegu zdarzeń. Doświadczałem trudności, których pokonanie możliwe było dzięki autorefleksji, werbalizacji problemu, „rozpisania siebie”, uświadomienia sobie spraw, na temat których milczą podręczniki: użycia wiedzy i niekonwencjonalnych sposobów poszerzających metodyczne spectrum. Obserwacje, wywiady, pisanie tekstu to złożone, polifoniczne procesy. Warto - moim zdaniem - im się przyglądać. Dlatego też, biorąc pod uwagę i przywołując własne przykłady, biorące swe źródła z odpowiednio ukształtowanego doświadczania, postanowiłem przedstawić, podzielić się zapisem swoistego dziennika dokumentującego (analitycznie i ewokatywnie) proces rozważań nad zadanym tematem: Autoetnografia. Chciałbym pokazać, jak kształtowały się moje rozważania, uchylić drzwi do warsztatowej „kuchni”, przywołać zapisywane w notesie pytania, frazy i hasła mające służyć za punkt wyjścia do dalszej refleksji, jej „całkowania” i reprezentacji w tekście. Jak przebiegało strukturyzowanie myśli, jakie lektury i pojęcia mnie inspirowały, jak wreszcie z owych często lakonicznych, wyrywkowych i nieskładnych notatek oraz spostrzeżeń grupowały się problemy i wątki warte rozwinięcia i rozwagi.

Na początek przedstawię wyimki i szkice, jakie sporządzałem podczas przygotowywania się do pisania, podczas lektur, poszukując inspiracji, zastanawiając się, co powinienem wziąć pod uwagę, zarówno jeśli chodzi o moje doświadczenie i elementy autoetnograficzne będące składowymi wcześniejszych prac, stosowane i brane pod uwagę $\mathrm{w}$ przedsięwzięciach badawczych, jak i o opracowania teoretyczne dotyczące przedmiotu moich zainteresowań, wreszcie prace, artykuły i książki innych autorów napisane w jawnie autoetnograficznym duchu.

Następnie z tych zapisów będę próbował stworzyć korespondujący układ, zgrupować je, stosownie rozwinąć, rozważyć na tle innych koncepcji, sprawdzić w innym polu metaforycznym i znaczeniowym. Podjąć grę, ryzyko, zmieszać substancje i treści niczym próbki w laboratorium języka i własnego umysłu. Badawczego i badającego.

Czytelnika zachęcam do własnych interpretacji, podejmowania i zestawiania podpowiadanych tropów. Odczytania ich na swój sposób. Uzupełnienia. Odniesienia do osobistych doświadczeń. Dialogu. Intersubiektywnej weryfikacji.

Od propozycji napisania tekstu do momentu jego rozpoczęcia w formie elektronicznej minęły cztery miesiące. Nie wynikało to z przyjętego niejako 
z góry planu, lecz ze zwykłego biegu zdarzeń znaczonego pracą, obowiązka$\mathrm{mi}$, tak zwanym codziennym i niecodziennym życiem. Proces trwa nadal. Ramy świata przeżywanego (Lebenswelt) i Lebenswelt procesu badawczego przenikają się, zakresowo o siebie zahaczają, rozmywając często swe i tak już subtelne granice. I last but not least przyświecała i wciąż przyświeca mi idea, hermeneutyczna perspektywa rzucająca szczególne światło na sposób odczytywania proponowanego tekstu. Przywołany cytat zwięźle oddaje sedno sprawy:

„Nie ulega wątpliwości, że nauka, niezależnie od tego, jakie wysuwałaby roszczenia epistemologiczne, stanowi pewną szczególną grę językową podejmowaną przez ludzi. Grę z pewnością najważniejszą, ponieważ w przeciwieństwie do znacznej części spekulatywnej metafizyki nie jest ona grą jałową, ale czymś, co ma niezwykle daleko idące konsekwencje dla organizacji naszego życia zbiorowego i sposobu bycia-w-świecie, tzn. dla naszego samorozumienia. Jeden $z$ aspektów emancypacyjnej funkcji hermeneutyki polega $\mathrm{w}$ istocie na dopuszczeniu do świadomości tych możliwości bycia, które wskutek wymaganego przez metodologię abstrahowania od przeżywanego doświadczenia z konieczności przemilcza i wyklucza projekt naukowo-technologiczny" (Madison 1993, s. 199).

Dodałbym jedynie i podkreślił, że emancypacyjna funkcja hermeneutyki mogłaby polegać także na dopuszczeniu do świadomości rozmaitych możliwości „pisania”, wyrażania doświadczenia i myśli oraz stosowania form ekspresji spoza konwencjonalnego repertuaru prezentacji naukowych.

\section{DZIENNIKI METODOLOGICZNE}

\subsubsection{6}

Odmieniam się przez słowa. Kondensuję i rozszczepiam. Pojęcia profilują praktyczne działania. Przy stosowaniu autoetnografii łatwo popaść w egzaltację, przesadę, przecenić istotność własnych stanów, zamiarów, odczuć. Doświadczenie, czyli zmysły, reakcje: zachwyt, odraza, wstręt, powściągliwość, przyjemność, jako wyznaczniki kierunku działania, opisu. Rozpoznaję osobiste preferencje. Staram się z dystansu spojrzeć na subiektywizm. Autoetnografia ma sens, jeśli stosowana jest $z$ umiarem, wyczuciem, proporcjonalnie do reszty składowych elementów. Uzupełnia „obraz” badawczego procesu. Pozwala uzasadnić wybory praktyczne, argumentacyjne. Źródło: „ja jestem Innym”. Nie można wyjść poza siebie w języku. W każdej formie wypowiedzi jesteśmy obecni jako jednostka $z$ całym osobistym, kulturowym bagażem, skrycie, mniej lub bardziej jawnie, świadomie. Jako konstrukt. Zdejmujemy i zakładamy pojęciową mas kę, która jednocześnie kryje i ujawnia. Przekształca. Informuje. Dokonuje transformacji na wielu poziomach: przekazu, formy, stylu, treści. Społeczne, kulturowe „ja” to niezbywalny komponent. Można porzucić pisanie jak Arthur Rimbaud albo proliferować „siebie”, mnożyć konstrukty jak Fernando Pessoa powołujący kolejne het e r on i my. Tworzyć zmienne punkty widzenia, które powołują dynamiczną perspektywę widzenia i opisu zjawisk. 
Wyznaczyć „autoetnograficzne” regulacje dotyczące własnego praktykowania antropologii. Bardziej ścisłe niż reguły metodologii kryteria uprawiania nauki.

\subsubsection{6}

Najbardziej efektywne momenty pozyskiwania materiału podczas badawczych przedsięwzięć miały miejsce, gdy zapominałem o metodologicznych dyrektywach. Poluzowałem metodyczne wskazówki. Dokonywałem alternacji. Rzeczywiste warunki rozbijały teoretyczne ramy. Szukałem warunków rozumienia zjawiska na „własną rękę”. Łączyłem metody: obserwację, swobodny wywiad, zapis, zdjęcia, praca pamięci.

Później stopniowo dokonuję idealizacji przeżywanej i postrzeganej rzeczywistości. Najwyżej — to, co niepowtarzalne, nieokreślone, marginesowe, ubieram w ilustrującą całość anegdotę.

\subsubsection{6}

Badacz/etnograf/antropolog zawsze - w pewnym sensie - był autoetnografem. Swe refleksje, działania filtrował przez wypracowany w danej dziedzinie aparat metodologiczny, i odwrotnie: metody weryfikowało jego/jej doświadczenie, osobowość, pochodzenie etc. Zawsze dysponował swym doświadczeniem (także teoretycznym), wybierając z niego historycznie, metodologicznie, terminologicznie uwarunkowane „esencje”. Eksponował to, co łatwo zmierzyć, opisać, powtórzyć, „zobiektywizować”, uprawomocnić. Co wpisuje się w poważny, komunikowalny dyskurs, to na czym daje się budować prawa o charakterze ogólnym, pozostawiając za kulisami publikacji i rozważań to, co ulotne, pozorne, ogólnie: niepewne składowe własnej naukowej osobowości. Emocje (złe i dobre), prozaiczne problemy, uwikłania, etyczne rozterki, czynniki, które kumulując się oddziaływały — jednak — na przebieg i wynik dociekań.

Ważne jest to co Ja przeżyłem, czego doświadczyłem, co uprzednio przeczytałem, wysłuchałem, co mnie kształtowało, i co Ja jako praktykujący antropolog chcę o „czymś” opowiedzieć.

Doświadczam teorii na sobie. Traktuję się instrumentalnie. Im bardziej chcę się określić, zdefiniować, wyabstrahować, tym więcej powiązań odczytuję. Ujawnia się relacyjny charakter powiązań ze światem, środowiskiem, ludźmi etc. Eksperymentuję, starając się wytrącić świadomość z utartych, udeptanych poznawczych ścieżek i konwencji. Zmiana warunków percepcji związana z przemieszczeniem, podróżą, lekturą, przemyśleniami. Wektory wyobraźni będące wypadkową - na przykład — literackich poszukiwań.

\subsection{1 .2016}

Łatwość zmiany tożsamości. Polytropos. Figura nieoznaczoności. Odyseusz inspirujący badawczy umysł. The man of twists and turns. Taktyki działania, praktycznego aplikowania opracowanej metody terenowej, której rygorystyczne 
wskazówki trudno zastosować (Michel de Certeau). Wynajdywanie siebie. Autoetnograficznie wrażliwy antropolog szuka praw, które nim w jego działalności badawczej kierują. Poprzez opowiadanie „siebie”, introspekcję, zapis stanów odczuwania, poruszeń, skojarzeń. To chyba warsztatowa konieczność. Świadome operowanie własnym bagażem kulturowym, rozpoznanie go poprzez udział w konkretnych sytuacjach kontaktu z ludźmi i środowiskiem, w sytuacjach opisu, zaburzenia toku myślenia, porządku, przyzwyczajeń, opracowania materiału. To wszystko ma swój niezaprzeczalny heurystyczny walor.

Emocje, subiektywne doznania są prawdziwe. Jak korespondują one $z$ wiedzą. Jak wpleść je w prawomocne wnioskowanie, by „ustawić się” $\mathrm{w}$ punkcie przecięcia tego, co uniwersalne i partykularne. Hermeneutycznie uprawomocnić.

Dostroić detektory emocji i zmysłów. Obserwować ich działanie, krążenie. Ciało zanurzone jest przecież $\mathrm{w}$ uniwersum kultury, przyrody, materialnego środowiska, przez nie kształtowane. Wzrastamy sensorycznie, wyrastamy z klimatu, krajobrazu, pełni przyzwyczajeń zapachowych, smakowych, słuchowych i dotykowych. Ciało doświadcza heterotopii, obcości, ciało doświadcza miasta. Habitus badacza kultury.

\subsubsection{7}

Jak rzeczywiście jest w nauce. Refleksje zwrotne. Refleksywne myślenie prowadzące do wypracowania deskryptywnej metodologii. Oscylowanie między, w dowolnej kolejności: Ja - procedury badawcze - kultura. Nazywanie przebiegów tych uwarunkowań i relacji. Dokonywanie semantycznych eksperymentów na języku, czasem na granicy komunikowalności. Świadectwo. Wyznanie nie tyle wiary, co „grzechów” procesu badawczego. Do tego potrzeba odwagi. Odsłonięcia. Języka. Wystawienia się na śmieszność, zarzuty. Podjęcia gry: mówię o sobie tekstem kultury, odgrywam dramatyczną rolę badacza w społecznym teatrze. Komedianta punktującego scjentystyczne pretensje, w sztuce pod tytułem "Jak przełożyć niezdyscyplinowane doświadczenie na autorytatywne pisanie".

\subsubsection{7}

Czy subiektywna forma wypowiedzi, zabarwiony literacko język może mieć walor dedukcyjnego rozumowania. Czy musi zabiegać o kategorie profesjonalnej kultury wypowiedzi przynależnej danej dziedzinie wiedzy. Czy realizacja normatywnych założeń nauki musi wykluczać z formy ekspresji jej twórcze, źródłowo-poetyckie podstawy.

Być może „własny”, wypracowany język, styl sięgający po literackie formy wyrazu jest bardziej ścisły („skuteczniej” wiążący różne poziomy doświadczenia). Dlaczego literackie pisanie pozbawiać waloru referencyjności, prawidłowego wnioskowania, intersubiektywności, w momencie gdy w naszym oglądzie spraw pewne koncepcje, terminy, znaczenia, kategorie jako pojęcia operacyjne 
zaczynają tracić swą wyjaśniającą moc, swe eksplikacyjne ostrze. Potrzebują innego/świeżego języka, który spełni tu regulującą funkcję. Taki język jest moim zdaniem bliższy autoetnografii, która buduje przecież przestrzeń dialogu i bliskości z czytelnikiem. Pozwala pokazać ludzki wymiar, ludzką twarz badacza i jego działalności.

\subsubsection{7}

Już wybór dyscypliny, tematu badawczego, problemu, perspektywy zależy od naszych predyspozycji mentalnych i społecznych. Nauczycieli, gustu, umiejętności współpracy, dialogu, łatwości w nawiązywaniu kontaktów, asertywności, umiejętności organizacji pracy, znajomości, operatywności. Autoetnografia to autoryzacja, własna sygnatura wpleciona $\mathrm{w}$ kalejdoskop nauki. Przecież chodzi o to, by - bazując na poprzednikach i tradycji — przeć do przodu, zakreślać nowe obszary, szukać odmiennych sposobów opisu zjawisk.

Szukam w swoim doświadczeniu tej osobliwości, która pozwoli na osobliwą perspektywę interpretacji.

\subsubsection{7}

Staram się dokonywać pomiaru temperatury swojej autorefleksji podczas praktyki badawczej. Autoindukcji. Czy autoetnografia może być zwartą koncepcyjnie propozycją. Eksplikatywną metodą. Jak ocenić, czy „coś” ma znaczenie dla efektów, konkluzji czy końcowych wniosków. Czy każdy autor jest zdolny i zobowiązany do pogłębionej autoprezentacji przy jednoczesnej próbie przyjęcia eks-centrycznej pozycji. Demaskacja jest także konstruktem. Nie są to łatwe zadania. Przypominają polifoniczną kompozycję. Wymagają jednoczesnego prowadzenia wielu głosów, kontroli równorzędnych planów, posługiwania się kontrapunktem, kolistym trybem rozpoznania. Łatwo tutaj o rozszczelnienie, dysonans, pojęciową dekompresję, zacieranie w tekście - nawet nieświadome śladów własnych ruchów, odstępstwo od własnych założeń, pogubienie, przegadanie etc., jeśli uparcie poszukiwać będziemy warunków możliwości myśli zdającej sprawę z każdego naszego kroku.

„Prawda świata przeżywanego jest praktyczna. Nieprecyzyjna, związana z konkretną sytuacją, ale bynajmniej nie urojona ani «względna» w sensie indywidualnego widzimisię. Wystarcza dla zaspokojenia potrzeb, do których się odnosi. Jest zawsze bliska intuicji: byty tego świata są bytami konkretnymi, danymi w swej naiwnej źródłowości, jakkolwiek zawsze w perspektywie uwarunkowanej szczególnymi punktami widzenia, ale związanymi pewną wzajemnością nietematyczną, która działa w kierunku wyabstrahowania odrębności cech subiektywnych. Ich dane znamionuje typowa ogólność, kiedy nie chodzi specjalnie o jednostki ludzkie, a ich określenia ze swej istoty są nieścisłe" (Patočka 1993, s. 30).

Spróbujmy odnieść te słowa do świata przeżywanego w sytuacji badawczej. Gdzie ona się kończy, a gdzie zaczyna. Jakie parametry o tym decydują. Czy na- 
stawienie badawcze implikuje syntezę i wyższą świadomość warunków przeżywania świata. Może „komplikuje”, na pewno problematyzuje jego przeżywanie.

\subsubsection{7}

Wytrawić się w praktyce, by rozwiały się opary abstrakcji. Rekonfiguracja. Metodologiczna refleksja być może powinna „oczyszczać” postrzeganie (na przykład przy użyciu, zastosowaniu fenomenologii). Zawieszać pojęcia, terminologie, sprawdzone sposoby interpretacji, teoretyczne moduły. W toku „zawieszania” jawię się jako palimsest, chronotop, „instytucja”, nie-miejsce, rezerwuar zapożyczeń, swój-obcy, poddany wtórnej socjalizacji, ogniwo obiegu uwarunkowań. Splot, spin. A naukowe przedsięwzięcie w swej konstrukcji przypomina wstęgę Möbiusa i pewien szczególny metaforyczny model narracyjny w niej zawarty. Podobnie jak podwójna spirala Le Corbusiera w Museé Mondiale obrazująca poznawczy model oparty na możliwości oglądu świata wchodząc po spirali zewnętrznej i zejścia spiralą wewnętrzną, by zwiedzać ekspozycję dotyczącą historii ludzkości, świata, człowieka, od wielkiego wybuchu po ciszę i pustkę na samym końcu zwiedzania (na podst. Kopacki 2008, s. 323). Sous rature.

„A z kolei główną cechę spiralnej podwójności stanowi nierozłączność segmentów: spirala jest zawsze podwójna i jej modelową realizacją okazuje się wstęga Möbiusa, o której wiadomo, że jej rozcięcie wzdłuż podłużnej osi nie skutkuje otrzymaniem dwóch rozłącznych figur. Tym samym jako model dynamiczny, czyli na przykład figura, po której porusza się podmiot - także podmiot literacki w ramach spiralnej przestrzeni narracyjnej — wstęga Möbiusa umożliwia mu przebywanie zarówno na zewnątrz, jak i wewnątrz własnej struktury" (Kopacki 2008, s. 334).

Ostatnie zdanie można odnieść do podmiotu badawczego i jego przestrzeni poznawczej oraz narracyjnej.

\subsubsection{7}

Ja versus przedmiot badań. Konstruuje jego sens przy jednoczesnej konstatacji warunków jego tworzenia. Mixtum compositum.

Szukam uprawomocnienia autoetnografii, jej heurystycznej wartości, kryteriów, jakie powinna spełniać, by nie stać się migotliwą, kruchą fasadą, za którą skrywamy swoje niedociągnięcia, niewiedzę, braki.

\subsubsection{7}

Jak autoetnografia, to pełną gębą. Podjąłem kilka prób wydania swojej dysertacji doktorskiej pt. „Lizbońska pastelaria. Antropolog jako obserwator obcej kultury. Studium metodologiczne". Niestety, z powodu braków finansowych publikacja nie doszła do skutku. Wydawnictwa oczekują sfinansowania większej części, a - jak wiadomo - uczelniane władze nie są skore do wsparcia. Zatem to dobra okazja, by przytoczyć publicznie kilka głębszych (auto)cyta- 
tów związanych z tematem tego tekstu, ponieważ znaczna część pracy miała autoetnograficzny rys. Dotyczyła między innymi weryfikacji we własnym doświadczeniu metody obserwacji uczestniczącej Jamesa P. Spradleya w lokalnym środowisku lizbońskiej pastelarii.

Oto kilka wyimków (kopiuj/wklej):

„[18.07.2009] W nowych warunkach trzeba wypracować sobie nowe warunki myślenia i pisania. Pogodzić aktywne poznanie z pisaniem i zmęczeniem, pogodą, rejestrowaniem danych, doświadczeniem, refleksją nad nimi, zapisywaniem, opisem... Trzeba się ułożyć w spokoju, przyjąć odpowiednią dla siebie postawę, wypracować czas pracy.

Dziś w Bellinhi od 11:05, przygotowany z notesami, wchodzimy, zamawiamy galão, zajmujemy dogodne miejsca w końcu lokalu, wyciągam ten notes, okazuje się, że wszystkiego za dużo, wszystko chcę ogarnąć, wzrok skacze z tematu na temat, ręka nie nadąża, czuję, że coraz więcej mi umyka, na czym się skoncentrować? Wszystko bombarduje zmysły, ludzie, zdarzenia, wystrój, sytuacje, w oczach łódzkie powidoki, obsługa ciągle na nas zerka, piszę, wypatruję, bez ładu motam różne wątki, przeskakuję, nie wykańczam, talerz, wysoka szklanka, sztućce, serwetki, kapelusz, torba, pióro, staram się koordynować, selekcjonować szum informacyjny, łapać w jakimś porządku, lecz szybko okazuje się, że tak się nie da, wydaje się, że gubię gdzieś słowa bądź używam niewłaściwych, szybkich, lakonicznych, ogólnych, powtarzam je, staram się prawie równolegle pismem podążać za obserwacją, niedyskursywne obrazy przekładać automatycznie na opis, piszę, markuję, rozmawiam z Agnieszką, próbuję odciągnąć od siebie uwagę, piszę dyskretnie, zapamiętuję. Powstałe wyobrażenia o terenowej pracy, które usilnie w sobie zwalczałem przygotowując się do wyjazdu, zmieniają się. Byłem na to przygotowany. Na tyle, na ile można się przygotować do spotkania z praktyką. Sprawdzić $\mathrm{w}$ doświadczeniu wiedzę wyczytaną z lektur.

Rozbieram się z wyobrażeń, warstwa po warstwie, ale nadal pozostaję w swojej skórze, w skórze niewypowiedzianych założeń własnej kultury. Dopiero w trakcie wyjazdu zaczynam uświadamiać sobie złożoność i oczywistość pojęciowego instrumentarium, którego na co dzień używam. Ukształtowanie percepcji, której podlegam, uformowanie sposobu percypowania wypracowanego w niepoddawanych dotychczas drobiazgowej refleksji rejestrach" (Darmach 2012, s. 35).

„Introspekcja, doświadczanie wewnętrzne to także kategorie badawcze, pozwalające przebywającemu — przez dłuższy czas - w terenie obserwatorowi uczyć się nie tylko poprzez «widzenie», "patrzenie», słowa, zapisy, notatki, ale również przez wszystkie zmysły i całe ciało, które staje się nośnikiem pamięci.

Etnografia to warsztat. Mozolna praca, której kulisy najczęściej pozostają niewyartykułowane. Kulisy, za którymi kryją się trudne wybory, zmiany miejsc, ciekawe zbiegi okoliczności, nieoczekiwane zdarzenia, relacje, zmiany perspektywy, zmagania i olśnienia, wpływające pośrednio na jakość pracy. Rozumienie i wyrażenie tego procesu częściowo przecież zdejmuje z nas odium niekompetencji. Etnografia to także i przede wszystkim aporetyczne oscylacje na różnych poziomach (będziemy do tego zagadnienia jeszcze wracać). Bycie "na zewnątrz» $\mathrm{i}$ «W środku». Przedzieranie się z epic do emic i odwrotnie. Również w rozważanej teraz kwestii metodologicznej" (Darmach 2012, s. 36). 
„Przygotowania do wyjazdu to nie tylko załatwianie stosownych «konieczności», pieniędzy, pakowania, to również uzgadnianie miejsca pobytu, to znajomości, mejle, wymiany, potwierdzenia, wpłaty, zakładanie kolejnych walutowych kont bankowych - odpowiednio wcześnie - by otrzymać kartę, to terminy, piny, i inne zbędne-niezbędne dokumenty. Przygotowanie to także świadome korzystanie $z$ doświadczenia własnego i innych, korzystanie $z$ refleksji z wcześniejszych wyjazdów, dłuższych lub krótszych podróży. Wyczulona uwaga i pewna doza możliwych przewidywań.

Wyobraźmy teraz sobie, że wyjeżdżamy daleko w teren. «Tam». Na długi okres. Im bliżej wyjazdu, tym bardziej wzmożona świadomość i uwaga skierowana na rzeczy zupełnie podstawowe, związane z zapewnieniem bezpiecznego pobytu, minimum komfortu, w czasie, który do pewnego stopnia pozostaje niewiadomą — przynajmniej w początkowej fazie. Wtedy, gdy krystalizują się bazowe ramy egzystencji w obcej kulturze. Gdy dochodzi do załamania nawyków codzienności, gdy wydeptuje się nowe ścieżki, przejścia, skróty, które czasem potrafią ocalić, ale także zgubić.

Pojechałem $w$ teren, odbyłem badania, przeprowadziłem wywiad. Co to tak naprawdę znaczy? Czy te czynności i okoliczności, które mogą do nich doprowadzić, są na tyle oczywiste, by można zupełnie obojętnie obok nich przechodzić? Zostawić je bez komentarza? Przeprowadzenie wywiadu czy obserwacji angażuje przecież różnorodne aktywności. Decydują często nieprzewidziane okoliczności, przypadek, okazja; często jest to wybór o konsekwencjach zmuszających do podejmowania zabiegów, na które nie mamy ochoty, które sprawiają trudności lub dla których brakuje nam po prostu cierpliwości. Trzeba dzwonić, oddzwaniać, przekładać terminy, uzgadniać miejsca spotkania, przełamywać i otwierać innych i siebie, reagować, zakładać i zdejmować maski, zmniejszać, zwiększać dystans, często siedzieć głodnym lub jeść coś niedobrego albo przebywać wiele godzin $\mathrm{w}$ zadymionym pomieszczeniu przy piątym rozwodnionym piwie, jakoś to wszystko rejestrować, wybierać i jeszcze za to wszystko płacić" (Darmach 2012, s. 39).

„Moje przedsięwzięcie terenowe odbywało się podczas dwóch wyjazdów, oddzielonych półrocznym okresem przebywania w Łodzi. Po pierwszym przyjeździe odległość i czas okazały się sprzyjające odkrywczej refleksji i ujawnianiu nowych aspektów podejmowanych już interpretacji. Tamten świat $z$ łódzkiej perspektywy jawił mi się jako bliski, a gdy wyjechałem po raz kolejny - podczas tego drugiego pobytu — pod sam jego koniec kulturowa rzeczywistość wydawała się paradoksalnie bardziej obca niż na początku. Oznaczało to nie więcej niż potrzebę odpoczynku. Porzucenie terenu, roli badacza i obserwatora. Przejście do tak zwanego normalnego życia. Postawa taka to wynik postępującej nieustannie, towarzyszącej badaniom introspekcji. Subiektywnych zapisków odczuć i wątpliwości. Spoglądania za siebie, w siebie oraz uważne odnotowywanie tego, co inni biorą za oczywiste (dane) i bezdyskusyjne. Taka postawa pozwala właśnie doświadczyć jednoczesnego bycia outsiderem i insiderem podczas przeprowadzania swojego badawczego projektu.

Ciągła introspekcja związana $z$ własnymi działaniami to zwykle sytuacja niecodzienna, kontrastująca z postawą zwykłego uczestnika zdarzeń. Wyrazem introspekcji mogą być teksty lub ich fragmenty, które kontrastują — także w swej 
kompozycji i środkach wyrazu $-z$ «obiektywnym» ujęciem właściwym naukowemu językowi. Dziś już tę kwestię mamy zbyt dobrze metodologicznie przepracowaną, by obawiać się stosowania autoetnograficznych strategii uobecniania siebie w tekście. Sam Spradley, w odległych czasach, gdy pisał swoją książkę o obserwacji uczestniczącej, dopuszczał introspekcję, a nawet zachęcał do niej (pomimo obecności jedną nogą $\mathrm{w}$ innym paradygmacie), upatrując $\mathrm{w}$ niej przydatnego narzędzia do zrozumienia nowych, odmiennych od powszednich przyzwyczajeń sytuacji, a także postępu w rozumieniu jakościowych procesów badawczych. To, moim zdaniem, jedno z najważniejszych dobrodziejstw wynikających $z$ dzielenia się (burzliwymi) historiami wewnętrznych przeżyć i wglądów związanych z uprawianiem, wymagającej warsztatowo, sztuki etnografii terenowej. Zawsze pozostają jeszcze - często dyskusyjne - walory artystyczne czy literackie" (Darmach 2012, s. 79-80).

\subsubsection{7}

Nasze autoetnograficzne, nawet najbardziej intymne i idiosynkratyczne przemyślenia (doznania, wgląd, milczenie) poddają się w końcu racjonalnej kategoryzacji języka, konwencji (nawet tej najbardziej „awangardowej”). Każdy nasz „ruch” w szeroko rozumianym terenie, zdarzenie, błąd, lektura, radość, rozmowa, unik może zmieniać znaczenie w zależności od teoretycznej perspektywy odczytu, zakresu i kontekstu interpretacji. Badamy siebie „poprzez język”, jego poziomy, wymiary, funkcje, dzięki niemu „rozbieramy” doświadczenie badawcze na części składowe, znaczące cząstki elementarne - niczym morfemy, których układy i krążenie zależą od naszej wrażliwości, wnikliwości, sztuki naszej interpretacji (można dodać, parafrazując zdanie Aldousa Huxleya na temat doświadczenia, że nie jest ono czystym przeżyciem, lecz tym, co z danym „przeżyciem” później zrobimy). Lub czy jesteśmy w stanie je wyrazić w języku zewnętrznym (metajęzyku) wobec języka potocznego, nawykowego, płynnego, zdawkowego.

Jak widać, pytania się mnożą, refleksja autoetnograficzna o autoetnografii może wpadać w pułapki antynomii (czy uratują nas rozważania Alfreda Tarskiego, odnoszą się one przecież do języków formalnych).

\subsubsection{7}

Antynomie, aporie - może najlepiej wyrażają i wyjaśniają je przypowieści. Przekazywanie wiedzy w formie historii, opowieści, alegorii. Poprzez poszukiwanie formy. Metonimie, metafory wyrażają napięcia poznawcze. Język najbardziej opiera się redukcji.

Tego dnia pojawia się mój pomysł napisania tekstu w formie metodologicznego metadziennika autoetnograficznych rozmyślań. Zapisywanie śladów myśli. W formie mapki nie-składnych refleksji. Myślników, przeskoków. Prowokacji do czytania między wierszami. Recyklingu dawnych doświadczeń w obszarze pamięci. Ukazanie - wspomnianej na wstępie - drogi poszukiwań ekwiwalentu doświadczenia w opisie, języku, by w konsekwencji stworzyć warunki po- 
rozumienia z czytelnikiem. Cały proces badawczy wydaje się poszukiwaniem porozumienia z czytelnikiem, recenzentem, naukowym środowiskiem, a często, by do tego porozumienia doszło, wiele spraw trzeba ukryć, przesłonić wyjaśniające Ja, pominąć jako zbędne, „nużące” lub nieprecyzyjne, trudne w odbiorze! „Wyszlifować”, dopasować do dyskursu, paradygmatycznego idiomu.

„Mityczny charakter epistemologicznego podejścia do nauki ukazał Gerald Holton, fizyk z Uniwersytetu Harwardzkiego, w swoich badaniach nad historią nauki współczesnej, badaniach, które nie są ani naukowe, ani epistemologiczne, lecz humanistyczne (geisteswissenschaftlich). Holton [...] próbował opierając się na rozróżnieniu między nauką prywatną i publiczną pokazać, w jaki sposób wyniki badań indywidualnych zostają faktycznie podporząakowane «racjonalności naukowej", z chwilą gdy naukowiec zwraca się do wspólnoty uczonych w poszukiwaniu aprobaty. Jak mówi Holton: «[...] nadawanie elementom oryginalnym kształtu wymaganego ze względu na publikację polega częściowo na ukrywaniu całej drogi od stadium prywatnego, na takim przedstawieniu wyników, żeby później sprawiały wrażenie wywiedzionych wprost $z$ jasno określonych przesłanek» (Holton 1973, s. 388)" (Madison 1993, s. 203).

\section{PODSUMOWANIE}

Chciałbym wyartykułować kilka najważniejszych wątków z wielu czasem tylko hasłowo przywołanych aspektów. Przedstawiłem ich wiele i w różnej formie, jako przyczynki do dalszej refleksji, jako pobudzenie skojarzeń, zaznaczenie śladu myśli, być może wartej rozwinięcia w rozważaniach Czytelnika. Jednak kilka kwestii wartych jest według mnie szczególnego podkreślenia.

Autoetnografia — jak już wielokrotnie na to w literaturze wskazywano ${ }^{1}$ może objawiać się zarówno w metodzie badawczej, być techniką pozyskiwania danych, jak i być efektem wyrażonym i wyrażanym w pisaniu, aktem autonarracji, strategią, w której łączy się i przenika to, co autobiograficzne, osobowe, z tym, co społecznie, kulturowo uwarunkowane. Jej status jest wciąż dyskutowany, $z$ rozmaitych względów doceniany lub (przeważnie $\mathrm{w}$ kuluarach) dyskredytowany. Jednym z zarzutów jest to, że autoetnografia może być wygodną „przykrywką" niekompetencji, niewiele mówiącym o naturze zjawisk subiektywnym „rozpasaniem”, któremu brak dystansu i dyscypliny. Pozbawionym rygoru i analizy dryfowaniem po mętnych wodach własnych doznań i problemów. Wątpliwym ekshibicjonizmem, a nadto po prostu kolejną konstrukcją, maską, sztafażem. Oczywiście może tak być, jeśli — tak jak w innych wypadkach podejdzie się do sprawy mało rzetelnie, pobieżnie. Nie wyjdzie się w refleksji dalej niż poza ilustrującą pracę anegdotę. Autoetnografia wymaga — tak mi się zdaje - podwójnego wysiłku. Ostrożności w przechadzaniu się po cienkiej linie, na granicy między nadinterpretacją, egzaltacją, komunikowalnością a war-

${ }^{1}$ Zob. m.in.: Bochner, Ellis 2016; Chang 2016; Denzin 1987; Muncey 2010; Reed-Danahay 1997; Kacperczyk 2014. 
tościowymi poznawczo rezultatami. Z przekonaniem mogę jednak stwierdzić (po lekturach i własnych skromnych próbach), że omawiany w tym tekście model, strategia uprawiania antropologii ma swój heurystyczny walor, zwłaszcza dla refleksji o charakterze metodologicznym. Wskazuje i otwiera nie eksplorowane do tej pory intensywnie pola możliwości. Ukazuje pułapki i istotne dla przebiegu pracy, a lekceważone imponderabilia. Opowiada o konieczności uruchomienia radaru czułego na badawczą samoświadomość realizującego projekt podmiotu.

Dziś traktując poważnie swe naukowe przedsięwzięcia, nie można przejść obojętnie obok tego rodzaju refleksji, wielopoziomowej introspekcji. Niezależnie od tego, czy „autoetnografia” objawi się w ten, czy inny omawiany tu sposób, na przykład otwartym tekstem, jako kluczowy komponent - w odpowiednio przez autora $z$ rozmysłem ułożonych proporcjach, to powinna ona być, moim zdaniem, niezbędnym elementem każdej naukowej działalności (stąd $\mathrm{w}$ tytule autoetnografia 2.0). Stosowana $\mathrm{w}$ harmonii, w proporcjach tworzących kompozycję, swoistą sygnaturę, w której naukowa terminologia spotyka i absorbuje autorski język, nawet język potoczny oraz, dajmy na to, formy i figury literackie jako istotne nośniki znaczeń. Bez względu na paradygmat i styl, $\mathrm{w}$ jakim powstaje kompozycja naukowego utworu. Pozytywistyczny, teoretyczny, postmodernistyczny, barokowy, inny.

Po wtóre, poza otwarciem na różne formy nie tylko językowej ekspresji (kolaż, performatykę, przypowieść, fotografię etc.) proces autoetnograficznego wglądu uczula i inspiruje do prób przyjęcia różnych, odmiennych punktów widzenia, „wyjścia poza siebie”, poza swoje przypadłości i nawyki. Nie bez przyczyny przywołałem Fernanda Pessoę (bardziej jego heteronimy) i Odyseusza jako stricte poznawcze figury, egzemplifikacje nastawienia, które krystalizują wyobraźnię, ukazując złożoność naszego postrzegania (jako uniwersalną cechę ludzkiej percepcji, zdolności rozumienia i wyjaśniania). Jesteśmy początkiem i końcem. Punktem emergencji, który jednocześnie łączy i rozszczepia różne punkty widzenia. Niczym kryształ o płynnej strukturze załamujący i przekazujący dalej światło. Stąd Polytropos. Politropia.

„Rozwarstwiając” siebie poprzez stosowanie autoetnografii, możemy trafić na zaskakujące wątki, podskórne iunctim (pozostawiam zupełnie na boku psychologię czy psychologizm), paradoksalnie „zagłębiając” się we własne uwarunkowania, stając się badawczym przedmiotem, rozpoznanym instrumentem, w konsekwencji świadomie „oddajemy głos” innym. Na przykład Pessoi, Sokratesowi, Johannesowi de Silentio, Don Kichotowi, Don Juanowi, Bronisławowi Malinowskiemu, Józefowi K. etc. Dajemy im przemówić poprzez siebie, być może w nowej roli, wyrażamy siebie poprzez nich, wplatając się tym samym w tę tkaninę odniesień humanistycznej (i nie tylko) materii.

Co być może najważniejsze dla naszych rozważań, można przyjąć - już na koniec — jeszcze jedną perspektywę myślenia o Autoetnografii. Mianowicie może ona uczynić fenomenologię produktywnym narzędziem dla antropolo- 
gii, angażując, łącząc jak spoiwo fenomenologię z hermeneutyką. „Produktem ubocznym" zastosowania fenomenologicznej metody (ejdetycznej redukcji) sa, jak wiemy, zawieszone, odłożone niejako „na bok” sądy, przed-sądy, przeświadczenia, warunki, założenia etc., czyli to, co interesuje antropologa, mogącego $\mathrm{w}$ tym wypadku w wykładni hermeneutycznej wymienione presupozycje analizować i interpretować.

Jak pisze Mary Warnock, rekapitulując w swej książce fenomenologiczny wątek myśli Martina Heideggera:

„Opis fenomenologiczny otwiera nam oczy, tłumaczy istotę i znaczenie tego, w co jesteśmy uwikłani. O metodzie fenomenologicznej mówi się też, że jest hermeneutyczna, ponieważ polega ona właśnie na odsłanianiu sensu. Świat ujmuje się tu jako kod czy system znaków, a metodę fenomenologiczną — jako instrument służący do ich odczytywania. Szczególnym elementem całego zbioru istniejących rzeczy, który domaga się wyjaśnienia, jest przede wszystkim Dasein — ludzka egzystencja jako taka. Heidegger używa wyrażenia «fenomenologia hermeneutyczna» również jako nazwy metody, którą ludzie mogą wykorzystywać w celu rozpoznawania samych siebie. Dzięki niej mogą zrozumieć swoistość własnego postrzegania i myślenia o świecie, bez niej zaś owo rozumienie tracą, choćby im się zdawało, że coraz lepiej poznają ten świat" (Warnock 2005, s. 68).

Dodałbym tu jeszcze moje autorskie rozróżnienie. W swojej antropologicznej działalności mówiłbym raczej o uprawianiu fenomenografii. Odrzucam, może raczej zawieszam, założenie o istnieniu „istoty” rzeczy, istoty zjawiska (a o eidos $\mathrm{w}$ gruncie rzeczy $\mathrm{w}$ fenomenologii chodzi), do której dotarcie aproksymacyjnie, ale jednak zakładamy ${ }^{2}$. Nie przeszkadza to jednak w czynieniu opisów kultury, jej materialnych, społecznych, duchowych aspektów prób opisania, dokumentacji sposobów egzystencji ludzkiej objawiających się we wszelkich dziedzinach życia i działalności człowieka, jego wytworów, artefaktów, idei, związanej z nim przestrzeni itd.

W zakres opisu egzystowania jak najbardziej wchodzi przedkładana i rozważana tu kategoria autoetnografii - autorefleksja. W jej ramach warto też spojrzeć na warunki wykonywania zawodu badacza (bardziej doznawania zawodu) przez pracownika uniwersytetu, nawet jeśli ta refleksja doprowadza do dosyć gorzkich konstatacji. Ewokacji trudności - jakby egzemplifikacji tego rodzaju doświadczenia autoetnografia wyjątkowo sprzyjała $-z$ jakimi dziś trzeba się mierzyć wchodząc „do akademii” i w niej funkcjonując. Praca jest piękna, daje oczywiście dużo zadowolenia, możliwości i satysfakcji, ale niewiele poza tym. Czujesz się ludzkim zasobem, gotowym do eksploatowania przez większość przełożonych w imię ekonomicznych wyników, słupków, rynku, stosowalności, opłacalności itd., w imię rozgrywek politycznych, biurokracji, parametrów

${ }^{2}$ Gdy obserwuję i staram się zrozumieć na swój sposób świat zjawisk kulturowych, coraz trudniej przychodzi mi pogodzić się z myślą, że mogą obowiązywać jakiegoś rodzaju stałe, niezmienne, ogólne prawa i wzory dające się sprawnie ująć w ramy spójnego systemu wiedzy i kategorii danej dziedziny. 
oraz środowiskowych nie zawsze jasnych niuansów życia naukowego. Do tego dochodzi borykanie się z permanentnymi problemami finansowymi oraz - co być może szczególnie dotkliwe — ze zwykłym brakiem przyzwoitości, poczucia odpowiedzialności i krótkowzrocznością wielu decydentów.

\title{
BIBLIOGRAFIA
}

Bochner Arthur P., Ellis Carolyn, 2016, Evocative Autoethnography: Writing Lives and Telling Stories, Left Coast Press, Walnut Creek, CA.

Chang Heewon, 2016, Autoethnography as Method, Routledge, New York.

Darmach Krystian, 2012, „Lizbońska pastelaria. Antropolog jako obserwator obcej kultury. Studium metodologiczne". Niepublikowana praca doktorska napisana pod kierunkiem Andrzeja Pawła Wejlanda, IEiAK UŁ, Łódź.

Denzin Norman K., 1997, Interpretive Ethnography. Ethnographic Practices for the 21st Century, Sage, London.

Holton Gerald J., 1973, Thematic Origins of Scientific Thought: Kepler to Einstein, Harvard University Press, Cambridge, Mass.

Madison B. Gary, 1993, Hermeneutyka Husserla jako przyczynek do dyskusji na temat wyjaśniania i rozumienia, w: Zdzisław Krasnodębski, Klaus Nellen (red.), Świat przeżywany. Fenomenologia i nauki społeczne, PIW, Warszawa.

Kacperczyk Anna, 2014, Autoetnografia - technika, metoda, nowy paradygmat? O metodologicznym statusie autoetnografii, „Przegląd Socjologii Jakościowej”, t. 10, nr 3, s. 32-74.

Kopacki Andrzej, 2008, Christian Kracht, tristesse royale i wstęga Möbiusa, „Literatura na Świecie”, nr 1-2: William Carlos Williams.

Muncey Tessa, 2010, Creating Autoethnographies, Sage, Los Angeles-London.

Patočka Jan, 1993, Filozofia kryzysu nauki wedtug Edmunda Husserla i jego koncepcja fenomenologii „świata przeżywanego", w: Zdzisław Krasnodębski, Klaus Nellen (red.), Świat przeżywany. Fenomenologia i nauki społeczne, PIW, Warszawa.

Reed-Danahay Deborah E. (red.), 1997, Auto/ethnography: Rewriting the Self and the Social (Explorations in Anthropology), Berg Publishers, Oxford-New York.

Warnock Mary, 2005, Egzystencjalizm, tłum. Monika Michowicz, Prószyński i S-ka, Warszawa.

\section{AUTOETHNOGRAPHY 2.0}

\author{
Krystian Darmach \\ (University of Wrocław)
}

\section{Summary}

This text is a methodological diary-a meta-autoethnography, an attempt to report on the course and formation of auto-reflection on various aspects of autoethnography in the broad sense. It is the reinterpretation of selected fragments of the author's own texts of an autoethnographic profile, and a description of the process by which the concept of the essay emerged. It addresses the role of autoethnography in the anthropological cognitive process and autoethnography's contemporary methodological status. The author intends to show how his reflections were shaped and to open the door to the scholar's "kitchen" by describing how the questions, phrases, and ideas inscribed in his notebook served as departure points for further reflection and representation in the essay. He tells 
how his thoughts were structured, what reading and ideas inspired him, and finally, how these often laconic, fragmentary, and disorganized notes and observations brought together the issues and themes worthy of anthropological expansion and consideration.

\section{Key words / słowa kluczowe}

autoethnography / autoetnografia, anthropological experience / doświadczenie, phenomenology / fenomenologia, diary / dziennik, methodology / metodologia, polytropos / politropia, Möbius Strip / wstęga Möbiusa 